\title{
PEMBERDAYAAN MASYARAKAT DALAM PENGEMBANGAN \\ AGRO WISATA KEBUN TEH DI KABUPATEN SOLOK PROVINSI SUMATERA BARAT
}

\author{
Rika Despica \\ Program Studi Pendidikan Geografi STKIP PGRI Sumatera Barat \\ despicharekha@yahoo.com
}

\begin{abstract}
The tea gardens in the region Kayu Aro, Solok regency, West Sumatra, provides a beautiful panorama and the cool air and it has the potential to be developed it is done by empowering the community, The aim of this study was to determine how pemberdayakan community in the development of agro-tourism tea gardens in the district Solok of West Sumatra province, community empowerment is done by (1) the development of conservation-based, ie the pattern of community development while maintaining the authenticity of agro-ecosystems by seeking the preservation of natural resources environment, history, culture, and recreation. How to community development can be done in stages namely, done before the area became the object of agrotourism and after being selected as the object of agrotourism, (2) the development of agro-based tourism community, intended pattern of community development that puts an agro-tourism as the empowerment of farming communities to be able to obtain value-added both in terms of agricultural products as of tourist visits and a double effect on the absorption of agricultural produce by tourism enterprises and developers by specifying area / agro tourism by the government as an area / region development and inventory of strengths agro-tourism and the synergies between the community, the role of tourism agencies and agricultural institutions in the development of agro-tourism so that it can improve the aesthetic value and natural beauty.
\end{abstract}

\section{Abstrak}

Kebun teh di kawasan Kayu Aro, Kabupaten Solok, Sumatera Barat, memberikan panorama yang cantik dan hawa sejuk dan hal ini berpotensi untuk dikembangkan hal ini dilakukan dengan cara memberdayakan masyarakat, Tujuan penelitian ini adalah mengetahui bagaimana pemberdayakan masyarakat dalam pengembangan agro wisata kebun teh di kabupaten Solok Provinsi Sumatera Barat, pemberdayaan masyarakat dilakukan dengan cara (1) pengembangan berbasis konservasi, yaitu pola pembinaan masyarakat dengan tetap mempertahankan keaslian agro-ekosistem dengan mengupayakan kelestarian sumber daya alam lingkungan hidup, sejarah, budaya, dan rekreasi. Cara pembinaan masyarakat dapat dilakukan secara bertahap yakni, dilakukan sebelum daerah menjadi obyek agro wisata dan setelah daerahnya menjadi obyek agro wisata, (2) pengembangan agro wisata berbasis masyarakat, dimaksudkan pola pembinaan masyarakat yang menempatkan agro wisata sebagai pemberdayaan masyarakat petani untuk dapat memperoleh nilai tambah baik dari sisi hasil pertanian maupun dari kunjungan wisatawan dan efek ganda dari penyerapan hasil pertanian oleh usaha pariwisata dan pengembang dengan cara menetapkan wilayah/daerah agro wisata oleh pemerintah sebagai daerah/wilayah pembinaan dan inventarisasi kekuatan agro wisata dan sinergi antara masyarakat, peran lembaga pariwisata dan lembaga pertanian dalam pembinaan agro wisata sehingga ini dapat meningkatkan nilai estetika dan keindahan alam.

\section{PENDAHULUAN}

Indonesia sebagai negara yang kaya akan sumber daya alam, terutama pertanian, memiliki prospek besar untuk mengembangkan berbagai usaha berbasiskan pertanian, termasuk pariwisata. Slogan Back to Nature yang semakin menggema tidak hanya di negara-negara maju tetapi juga negara-negara berkembang termasuk Indonesia, memperkuat terjadinya perubahan preferensi 
wisatawan global maupun domestik. Kecenderungan ini merupakan tanda semakin tingginya permintaan terhadap wisata alam dan sekaligus membuka peluang bagi pengembangan produk-produk agribisnis baik dalam bentuk kawasan ataupun produk pertanian yang mempunyai daya tarik bagi wisatawan.

Kebun teh di kawasan Kayu Aro, Kabupaten Solok, Sumatera Barat, memberikan panorama yang cantik dan hawa sejuk. Sayangnya, kebun teh tersebut terbatas hanya sepintas lalu saat wisatawan melewati kebun teh untuk menuju Danau Kembar dan belum terkelola sebagai agrowisata dengan baik, rencana mengembangkan kebun teh itu menjadi agrowisata telah di rencanakan oleh pemerintah Kabupaten Solok. Kebun teh Kayu Aro tersebut termasuk kebun teh terluas di dunia. Sejarahnya pun sangat kuat, yaitu kebun teh tertua di Indonesia. Selain mengembangkan kebun teh tersebut, pihaknya juga ingin terus mengembangkan fasilitas dan sarana di seputar Danau Kembar dan Danau Singkarak. Salah satu pengembangannya adalah telah dibuatnya dua dermaga di Danau Singkarak.

Wisatawan bisa naik kapal dari dermaga untuk keliling Danau Singkarak. Selain itu, pengembangan lainnya adalah akomodasi di Kabupaten Solok, hotel di kabupaten tersebut masih seputar di daerah Kota Solok. Sementara di daerah Danau Singkarak hanya ada dua hotel melati dan wisma penginapan sederhana di Danau Kembar.

"Cottage akan dibangun di Danau Kembar di sepanjang perjalanan, panorama cantik sawah dan kebun, serta rumah-rumah tradisional masyarakat.( Pemda Kab, Solok 2012)

Selain itu peluang sektor pariwisata cukup prospektif, karena selain merupakan salah satu penghasil pertumbuhan ekonomi pariwisata, sektor pariwisata diharapkan dapat berpeluang untuk dapat menjadi pendorong pertumbuhan sektor pembangunan lainnya, seperti sektor perkebunan, pertanian, perdagangan, perindustrian dan lain-lain. Salah satu unsur dari sektor pertanian yang saat ini belum tergarap secara optimal adalah agro wisata (agro tourism). Potensi agro wisata tersebut ditujukan dari keindahan alam pertanian dan produksi di sektor pertanian yang cukup berkembang. Agro wisata merupakan rangkaian kegiatan wisata yang memanfaatkan potensi pertanian sebagai obyek wisata, baik potensi berupa pemandangan alam kawasan pertaniannya maupun kekhasan dan 
keanekaragaman aktivitas produksi dan teknologi pertanian serta budaya masyarakat petaninya. Kegiatan agro wisata bertujuan untuk memperluas wawasan pengetahuan, pengalaman rekreasi dan hubungan usaha di bidang pertanian yang meliputi tanaman pangan, holtikultura, perkebunan, perikanan dan peternakan. Disamping itu yang termasuk dalam agro wisata adalah perhutanan dan sumber daya pertanian (Satrayuda, 2010)

Perpaduan antara keindahan alam, kehidupan masyarakat pedesaan dan potensi pertanian, bilamana ditata secara baik dan ditangani secara serius dapat mengembangkan daya tarik wisata bagi satu daerah tujuan wisata. Agro wisata yang menghadirkan aneka tanaman dapat memberikan manfaat dalam perbaikan kualitas iklim mikro, menjaga siklus hidrologi, mengurangi erosi, melestarikan lingkungan, memberikan desain lingkungan yang estetis bila dikelola dan dirancang dengan baik. Dengan berkembangnya agro wisata di satu daerah tujuan wisata akan memberikan manfaat untuk peningkatan pendapatan masyarakat dan pemerintah. Dengan kata lain bahwa fungsi pariwisata dapat dilakukan dengan fungsi budi daya pertanian dan pemukiman pedesaan dan sekaligus fungsi konservasi. Upaya pengembangan agro wisata pedesaan yang memanfaatkan potensi pertanian, dan melibatkan masyarakat pedesaan, dapat berfungsi sebagai pemberdayaan masyarakat selaras dengan pemberdayaan masyarakat berbasis pariwisata (community based tourism).

Pemberdayaan masyarakat dimaksud adalah agro wisata yang dapat mengikutsertakan peran dan aspirasi masyarakat pedesaan selaras dengan pendayagunaan potensi sumber daya alam dan sumber daya manusia yang dimilikinya. Persoalannya adalah bagaimana masyarakat pedesaan dibina secara berkesinambungan, agar potensi-potensi yang dimiliki daerah digali secara optimal, sehingga dapat memberikan hasil maksimal bagi petani, masyarakat desa, pengusaha dan menjadi sumber pendapatan yang dapat diandalkan. Sejalan dengan itu perlu adanya pola pembinaan agro wisata agar para pelaku pariwisata dan pelaku pertanian secara sinergis dapat merencanakan, menyusun, memprogramkan agro wisata yang bermanfaat bagi masyarakat, pengusaha dan pemerintah.

\section{METODOLOGI}

Berdasarkan latar belakang masalah, fokus penelitian dan tujuan penelitian kualitatif dengan tujuan mencari informasi sebanyak mungkin melalui informan 
dan pengamatan dilapangan. Teknik penelitian ini dilakukan melalui wawancara, observasi dan dokumentasi di lapangan sehingga dapat dicapai tujuan penelitian. Penelitian ini dilakukan di kabupaten Solok Provinsi Sumatera Barat. Pemilihan sampel ini menggunakan metode purposive sampling (penunjukan) yaitu penelitian sampel berdasarkan pada karakteristik tertentu.

\section{PEMBAHASAN}

Pemberdayakan msyarakat dalam pengembangan agrowisata kebun teh di kabupaten Solok Provinsi Sumatera Barat dapat dilakukan dengan Pengembangan agro wisata pada kehidupan masyarakat pedesaan, hal ini sangat mudah dilakukan karena masyarakat desa masih memiliki sifat gotong royong yang mendalam, yang membuktikan bahwa kehidupan selalu dibarengi dengan berbagai upaya yang dapat menghasilkan bekal bagi kelangsungan hidup. Pertanian maupun berkebun adalah salah satu usaha yang sejak lama dan turun temurun, menjadi bagian mata pencaharian masyarakat di daerah Kabupaten Solok, usaha perkebunan teh telah membentuk pola hidup masyarakat tidak hanya sekedar merawat dan mengolah kebun, tetapi apa yang mereka kerjakan dengan tanpa disadari telah membentuk satu daya tarik bagi orang lain yang melihatnya. Bentangan kebun teh yang disajikan yang menghampar luas, telah membentuk nuansa alam. Kehijauan ibarat permadani yang tak terbatas setiap mata memandang membuat rona alam yang menakjubkan sehingga menjadi daya tarik. Hijaunya daun teh di lereng bukit telah membentuk pola yang indah dan menyejukan pandangan.

Masyarakat petani dan hasil garapannya merupakan keterpaduan harmonis yang dapat mendorong perkembangan kepariwisataan namun hal ini dapat dilakukan dengan cara memnberdayakan masyarakat dengan memanfaatkan potensi yang telah ada serta hal ini merupakan rutinitas petani sehari-harinya. Pemberdayaan masyarakt dalam pengembangan agro wisata kebun teh dapat dilakukan dengan cara:

Pertama pengembangan agro wisata berbasis konservasi, dimaksudkan pola pembinaan masyarakat dengan tetap mempertahankan keaslian agroekosistem dengan mengupayakan kelestarian sumber daya alam lingkungan hidup, sejarah, budaya, dan rekreasi. Cara pembinaan masyarakat dapat dilakukan secara bertahap yakni, dilakukan sebelum daerah menjadi obyek agro wisata dan setelah daerahnya menjadi obyek agro wisata. Pembinaan obyek agro wisata adalah berupa 
pengarahan kepada setiap anggota masyarakat agar mempunyai persepsi yang sama dalam menghadapi berbagai permasalahan manakala wilayahnya akan dijadikan agro wisata. Apabila masyarakat mempunyai persepsi yang sama, maka mereka akan memberikan sikap dan tingkah laku yang mendukung agro wisata. Sedangkan pembinaan masyarakat telah menjadi agro wisata yang paling penting adalah mengendalikan diri, artinya keberhasilan masyarakat harus dipertahankan jangan sampai luntur

Kedua pengembangan agro wisata berbasis masyarakat, dimaksudkan pola pembinaan masyarakat yang menempatkan agro wisata sebagai pemberdayaan masyarakat petani untuk dapat memperoleh nilai tambah baik dari sisi hasil pertanian maupun dari kunjungan wisatawan dan efek ganda dari penyerapan hasil pertanian oleh usaha pariwisata dan pengembang dengan cara menetapkan wilayah/daerah agro wisata oleh pemerintah sebagai daerah/wilayah pembinaan dan inventarisasi kekuatan agro wisata dan sinergi antara masyarakat, peran lembaga pariwisata dan lembaga pertanian dalam pembinaan agro wisata sehingga ini dapat meningkatkan nilai estetika dan keindahan alam.

Lingkungan alam yang indah, panorama yang memberikan kenyamanan, dan tertata rapi, akan memberikan nuansa alami yang membuat terpesona orang yang melihatnya. Alam ciptaan Tuhan Yang Maha Kuasa dipadukan dengan kemampuan manusia untuk mengelolanya, menimbulkan nilai estetika yang secara visual dapat diperoleh dari flora, fauna, warna dan arsitektur bangunan yang tersusun dalam satu tata ruang yang serasi dengan alam. Setiap pengembangan agro wisata tentu memiliki nilai- keserasian sendiri dan manfaat, pertimbangan secara mendalam terhadap komponen pendukung seperti bangunan yang dibuat dari beton, hendaknya dapat dijadikan pertimbangan untuk dapat dihindari keberadaannya. Bangunan yang didesain sedemikian rupa, yang dapat menyatu dengan alam, itulah yang diharapkan keberadaannya, oleh karena itu dalam pengembangan agro wisata dibutuhkan perencanaan tata letak, arsitektur bangunan, lanskap yang tepat.

Hal ini selaras dengan pendapat (Yoeti:1996), dimana Upaya pengembangan objek wisata sangat ditentukan sekali oleh kemampuan dari pihakpihak pengelola wisata daerah yang bersangkutan, dengan kata lain berhasil atau tidaknya suatu daerah dikembangkan menjadi daerah tujuan wisata ditentukan oleh pihak pengelola dan sikap masyaraka 
Kesuksesan dalam pembangunan pariwisata diperlukan pemahaman baik dari sisi pemerintah selaku regulator maupun dari sisi pengusaha selaku pelaku bisnis. Pemerintah tentu harus memperhatikan dann memastikan bahwa pembangunan pariwisata itu akan mampu memberikan keuntungan sekaligus menekan biaya sosial ekonomi serta dampak lingkungan sekecil mungkin (Pitana dan Diarta:2009).

\section{KESIMPULAN}

Berdasarkan pembahasan di atas maka penelitian ini dapat disimpulakan sebagai berikut:

1. Pemberdayaan masyarakat dalam pengembangan agro wisata kebun teh dapat dilakukan dengan pengembangan berbasis konservasi, yaitu pola pembinaan masyarakat dengan tetap mempertahankan keaslian agro-ekosistem dengan mengupayakan kelestarian sumber daya alam lingkungan hidup, sejarah, budaya, dan rekreasi. Cara pembinaan masyarakat dapat dilakukan secara bertahap yakni, dilakukan sebelum daerah menjadi obyek agro wisata dan setelah daerahnya menjadi obyek agro wisata. Pembinaan obyek agro wisata adalah berupa pengarahan kepada setiap anggota masyarakat agar mempunyai persepsi yang sama dalam menghadapi berbagai permasalahan manakala wilayahnya akan dijadikan agro wisata

2. Pemberdayaan masyarakat dalam pengembangan agro wisata kebun teh dapat dilakukan dengan pengembangan agro wisata berbasis masyarakat, dimaksudkan pola pembinaan masyarakat yang menempatkan agro wisata sebagai pemberdayaan masyarakat petani untuk dapat memperoleh nilai tambah baik dari sisi hasil pertanian maupun dari kunjungan wisatawan dan efek ganda dari penyerapan hasil pertanian oleh usaha pariwisata dan pengembang dengan cara menetapkan wilayah/daerah agro wisata oleh pemerintah sebagai daerah/wilayah pembinaan dan inventarisasi kekuatan agro wisata dan sinergi antara masyarakat, peran lembaga pariwisata dan lembaga pertanian dalam pembinaan agro wisata sehingga ini dapat meningkatkan nilai estetika dan keindahan alah.

\section{DAFTAR PUSTAKA}

A. J. Muljadi. 2009. Kepariwisataan dan Perjalanan. Jakarta:PT Raja Grafindo Persada. 
Bakaruddin, 2008. Perkembangan dan Permasalahan Kepariwisataan. Padang: UNP Pres.

Gumelar s. Sastrayuda, 2010. Leisure, strategi pengembangan dan pengelolaan resort and leisure 